\title{
Ranchers plan to protect water quality
}

Here are some signs of the times:

- Central Valley dairy farmers are being asked to take increasingly stringent measures to keep manure out of surface water.

- Coastal vegetable producers are constructing erosion control projects to keep pesticides and sediment from flowing into the Monterey Bay National Marine Sanctuary.

- North Coast ranchers, vineyard managers and other private landowners are developing comprehensive water quality management plans for their properties.

Even though the Clean Water Act has been in place for more than 20 years, only in recent

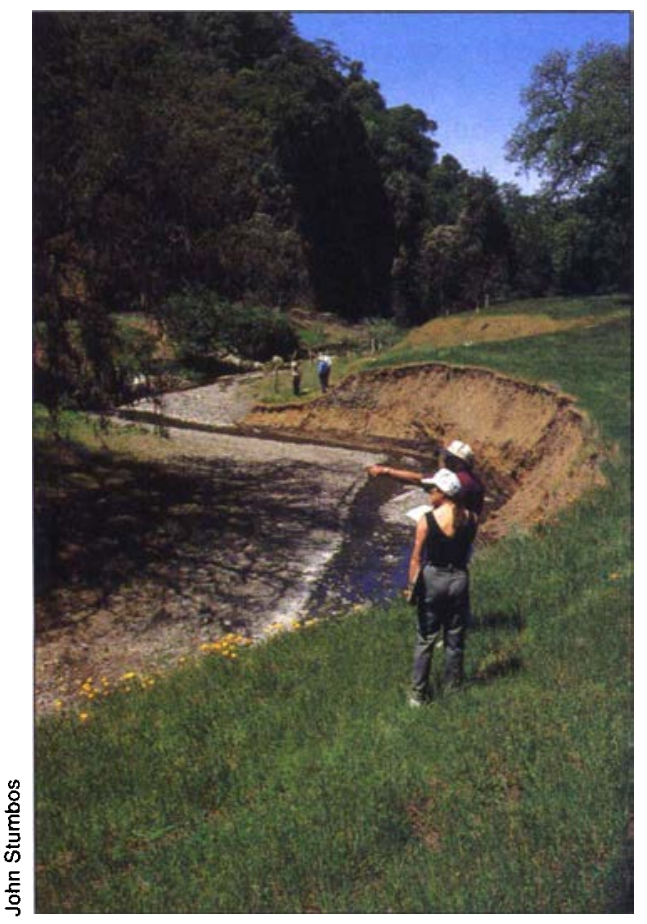
years have regulators shifted their focus from point-source to nonpoint source water pollution - pollution that results from diffuse discharges throughout the environment. Federal and state regulatory agencies are seeking reductions in sediment, nutrients, pesticides and pathogens, particularly in environmentally sensitive or "impaired" watersheds. (The State Water Resources Control Board designates rivers, lakes and other water bodies with damaged beneficial uses as impaired.) In some cases, especially on the North Coast, impaired watersheds suffer from seriously degraded habitat for endangered runs of salmon and steelhead.

Coastal runs of Coho salmon (October 1996, May 1997) and steelhead (August 1997) have been listed under the federal En-

In the Ranch Water Quality Planning Short Course, students learn how to assess erosion and potential sedimentation. In the foreground are Christine Wright-Shacklett and Chuck March. dangered Species Act. These runs join the winter run of Central Valley chinook (Jan. 1994) as either threatened with or in danger of extinction throughout all or a significant portion of their range. A decision on two other proposed listings - spring and fall runs of Central Valley chinook salmon - has been delayed until September 1999.
"A listing puts increased urgency and emphasis on water quality issues throughout the range of the listed fish," says Chris Dewees, marine fisheries specialist with the California Sea Grant Program. "Whatever we can do to improve water quality will ultimately help the outlook for salmon and steelhead."

In 1995 the livestock industry forged an agreement with the State Water Resources Control Board to address water pollution issues. The agreement is spelled out in the California Rangeland Water Quality Management Plan. It provides for a voluntary and cooperative approach to comply with the requirements of the Clean Water Act and the Coastal Zone Management Act through the development of individual ranch water quality plans or jointly developed watershed plans.

"There are a number of reasons for a landowner to develop a ranch water quality plan," says John Harper, UC Cooperative Extension livestock and natural resources advisor for Mendocino and Lake counties. "One of the most important is it ensures that should a complaint ever be filed with a regional water quality control board, the rancher would have documentation outlining efforts to protect or improve water quality."

Harper is part of a multidisciplinary team of advisors, specialists and faculty who have been tackling water quality issues through the Rangeland Watershed Program. He and other UC Cooperative Extension advisors have been teaching a Ranch Water Quality Planning Short Course that is one of the most visible and important components of this program. The course provides 20 hours of classroom instruction on water quality laws, hydrologic function in upland watersheds and associated streams, and identification and control of nonpointsource pollution. Participants first develop a brief assessment of current water quality status, current and proposed management changes, and plans to monitor those changes. In the five classroom sessions, students learn how to monitor the success or failure of the plan and how to take corrective actions. The course culminates 
with a field trip to a site, such as the UC

Hopland Research and Extension Center, where participants practice their assessment skills on watershed problems and then discuss them with local water quality officials.

"The field trip is essential to this because it gives people a chance to express their viewpoints and discuss them with regulators," says Harper. "Face-to-face meetings help to break down communication barriers and move both parties toward solving real-world problems."

Class participants develop a working knowledge of an analytical tool called a "Sediment TMDL Inventory and Monitoring Worksheet," which helps the landowner document different sources of natural and human-caused erosion, geological processes at work, probable causes and potential control measures. For instance, most human-caused erosion on the North Coast is associated with roads, which can result in gully erosion that may have been caused by road cut failure and could be remedied by grade stabilization. "TMDL," or Total Maximum Daily Load, is the threshold regulators are establishing for different pollutants on river systems whose watersheds have been deemed impaired. A photographic record is also encouraged to monitor changes over time and to leave a legacy to ranch heirs. The worksheet was developed by UC Davis Postgraduate Researcher David Lewis in collaboration with Harper and Rangeland Watershed Specialist Ken Tate.

The worksheet also gives ranchers and regulatory officials a common point of reference from which to work in analyzing specific NPS problems. "The form can do as little or as much for you as you want it to," Holly Lundborg, an engineering geologist with the North Coast's California Regional Water Quality Board, told class participants at a May field trip to the Hopland REC. She encouraged them to be creative in devising reasonable mitigation measures to prevent erosion problems. Some mitigation measures - like rip rap to dissipate energy from culvert water - seem fairly obvious to long-time ranchers like Dick Keithly, who owns 2,500 acres near Lakeport.

"I know how to manage these things because I've been doing it my whole life," Keithly says. "The main thing I'm learning is the terminology and that's been a great help for me. It all boils down to common sense where erosion is concerned."

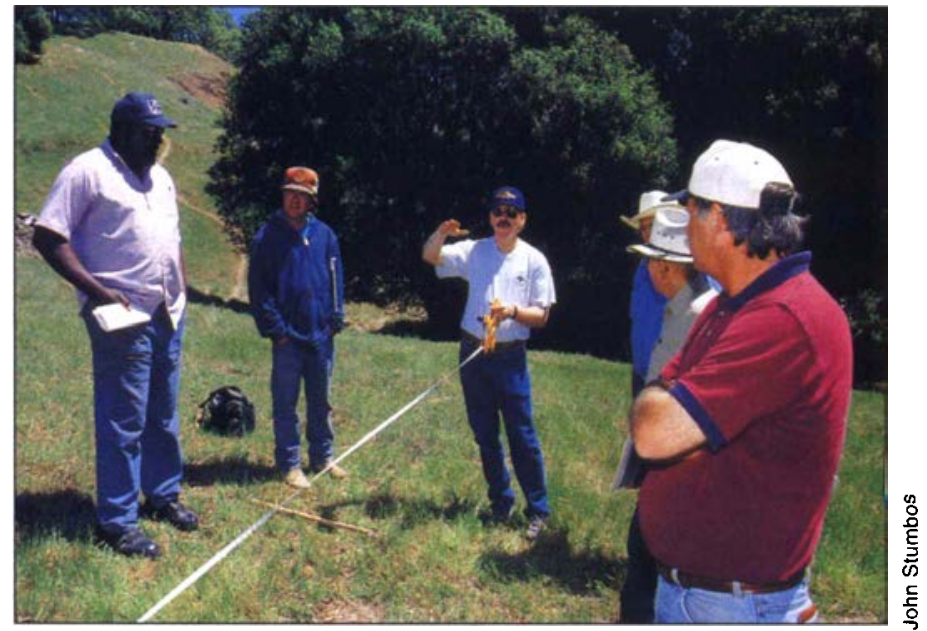

Livestock and natural resources advisor John Harper, center, demonstrates how to determine percentage ground cover to estimate the amount of livestock forage remaining on rangeland. servation Service has also been a partner in the delivery of the short courses throughout the state.

Between September 1997 and June 1998, plans were completed through this short course for nearly 500,000 acres along the north and central coasts, in the San Joaquin Valley foothills and in the Sierra Nevada. In the current year 150 ranches completed water quality plans in 15 short courses. The short courses have been endorsed by both the federal Environmental Protection Agency and regional water quality officials as a way for land users to address water quality concerns. State and local Farm Bureau, California Cattlemen's Association, California Wool Growers Association and local Resource Conservation districts all support and endorse the short courses.

Two proposals now winding their way through the California Legislature would have an impact on the way state regulators deal with coastal NPS pollution and could affect the need for programs like the Ranch Water Quality Planning Short Course. Both measures - S.B. 227 and S.B. 390 - are authored by State Senator Deirdre Alpert (DCoronado). The California Cattlemen's Association and the California Farm Bureau Federation

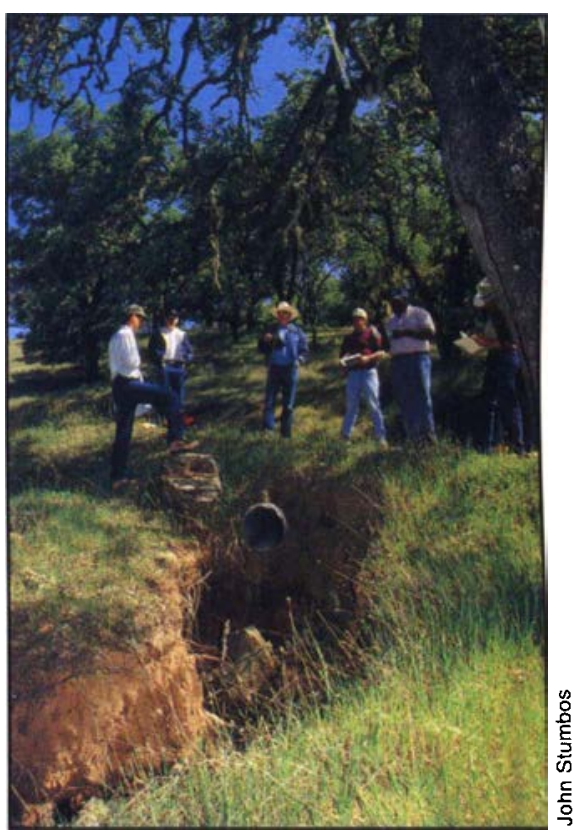

Culvert water concentrates intermittent high periods of runoff creating a "headcut." Left unchecked, headcuts can carve deep into a hillside, damaging vegetation, increasing erosion and, in severe cases, lowering the water table. 
are both working with the senator to ensure the final language of the legislation includes incentives for voluntary efforts to address NPS pollution.

The Rangeland Watershed Program has been involved in other water quality issues as well, such as when the San Francisco Public Utilities Commission and Contra Costa Water District considered moratoriums on livestock grazing in their watersheds because they feared cattle might contaminate their drinking water supplies with Cryptosporidium parvum. Key faculty in hydrology, microbiology, ecology, animal health and other disciplines have supplied science-based information to such controversies. In addition to George and Tate, they include Rob Atwill, a veterinarian and environmental health specialist with the Veterinary Medicine Teaching \& Research Center; Randy Dahlgren, a UC Davis biogeochemist; and Barbara Allen-Diaz, a UC Berkeley range ecologist. Atwill and Tate are analyzing the links between grazing and waterborne pathogens including Cryptosporidium parvum. Dahlgren's laboratory is quantifying nutrient flow processes that directly affect rangeland water quality. Allen-Diaz is studying biodiversity in riparian areas under various grazing schemes.

Related research is taking place on nine coordinated experimental and demonstration watersheds at the Sierra Foothill and Hopland research and extension centers and the San Joaquin Experimental Range, where different grazing, fire and other treatments are under study. This summer UC will be evaluating all its projects dealing with watershed management and will conduct focus group interviews with several of the state's many watershed groups to assess current research and extension efforts. Additionally, an inland fisheries specialist will join the team to work on interrelated water quality and endangered species issues.

\section{Research update}

\section{New direction for Sierra Nevada forests}

$\mathrm{P}$ rompted by concerns about the health of the Sierra Nevada, Congress requested in 1993 that the entire ecosystem be reviewed by a panel of independent scientists. The result was the \$6.6 million Sierra Nevada Ecosytem Project (SNEP). Led by UC Davis water resources specialist Don Erman, the approximately 140 scientists who analyzed existing knowledge of the Sierra Nevada delivered the SNEP report to Congress in 1996.

While Congress has done little with the SNEP report, it has had far-reaching consequences for the Sierra Nevada. Notably, SNEP led to fundamental changes in the way the U.S. Forest Service manages the region's 11 national forests, which encompass 13 million acres. SNEP concluded that one reason for the Sierra Nevada's troubles is that conservation issues cross the boundaries of individual forests and land ownerships. Accordingly, rather than managing these 11 forests individually, the Forest Service is developing a rangewide plan de- signed to protect and restore the land as well as to provide benefits for people. This new approach is called the Sierra Nevada Framework for Conservation and Collaboration, or Framework for short.

"We are heading towards broader, ecosystem management with sustainability of all resources as our primary motivating force," says Chris Holmes, a Forest Service spokesman in Washington DC. "We will work across the whole landscape in the Sierra Nevada and coordinate with nonfederal lands."

One of the first steps of the Framework was the 1998 Sierra Nevada Science Review. Based on SNEP and other current scientific information, seven scientists at the Forest Service's Pacific Southwest Research Station identified the most urgent rangewide conservation issues for national forests in the Sierra Nevada.

Based on the Science Review, the Forest Service is developing an Environmental Impact Statement (EIS), which is due out this summer. 